\title{
Visszatértek a hódok - áldás vagy átok?
}

\author{
Czabán Dávid ${ }^{1}$, Gruber Tamás ${ }^{2}$ \\ ${ }^{1}$ Kaposvári Egyetem, Vadbiológiai és Etológiai Tanszék \\ 7400 Kaposvár, Guba Sándor u. 40. \\ ${ }^{2}$ WWF Magyarország, 1141 Budapest, Álmos vezér útja 69/A. \\ e-mail: david.czaban@gmail.com
}

\begin{abstract}
Összefoglaló: Az eurázsiai hód (Castor fiber) őshonos faj, mely a XX. század elején majdnem kihalt, de a visszatelepítési programok hatására mára újra meghódította az eredeti elterjedési területét. Magyarországon az 1980-as évek végén jelent meg újra, a Szigetközben, ausztriai telepítések nyomán. A WWF Magyarország 1996-2008 között 234 példányt engedett szabadon. 2007-ben a hazai állományt 500 egyedre, 2011-ben 718-905 közé becsülték. 2015-ben már 2500-3000, 2017-ben pedig legalább 4000 egyed él hazánkban. Bár nincsenek rendszeres, az egész ország területére kiterjedő felmérési adataink, nagy valószínűséggel ma már Magyarország teljes területén jelen vannak a hódok. Egyre gyakrabban jelennek meg az emberi környezetben, de komolyabb konfliktusok föleg a FHNP területéröl ismertek. Az ember után a második leginkább tájátalakító faj, tevékenységének hatása egyaránt lehet pozitív és negatív. A legfontosabb konfliktus pontok: (1) a fadöntéssel jelentős gazdasági kárt okozhatnak, (2) az üregásással a gátakat és a töltéseket meggyengíthetik, valamint (3) a hódgátak árvíz- és belvízveszélyt okozhatnak. Léteznek hatékony megoldások, melyeket tesztelni kellene a hazai viszonyok között. Sürgető lenne egy fajkezelési terv elkészítése. Csehországi mintára egy hármas zónarendszer kidolgozása javasolt: az elsőben („A” Zóna) a hódok zavartalanul élhetnek, a másodikban korlátozottan gyéríthetők („B” Zóna) és a harmadikban pedig az ott megjelenő egyedek haladéktalanul eltávolíthatók („C”Zóna).
\end{abstract}

Kulcsszavak: Eurázsiai hód, menedzsment, hódkár, állományszabályozás

\section{Irodalmi áttekintés}

Az eurázsiai hód (Castor fiber) ökoszisztéma mérnök faj, amely környezetét nagymértékben képes átalakítani (Jones et al. 1994). Leginkább üregekben lakik, amelyeket meredek partoldalba szeret ásni. Ezek hossza változó, 1-10 méter közöttiek, egy territóriumon belül általában több is található. Az üregek időnként beszakadnak, ezeket vagy elhagyják, vagy befedik azokat. Ezek a kupacok faágakból és sárból épülnek, lehetnek akár 2-3 méter magasak is, ezek a hódvárak. Az üregek és várak bejárata minden esetben a víz alól nyílik (Müller-Schwarze 2011). Alacsony vízszint esetén (1 méternél kisebb), az állatok gátat építenek, 
ezzel megemelik és stabilizálják a vízszintet. A gátak felett kisebb-nagyobb tavak alakulnak ki, amelyek a dombosabb területeken csak néhány négyzetméteresek, de sík területeken jóval nagyobb területeket is eláraszthatnak. Hazai vizeken a gátak többsége 2-5 méter hosszú, magasságuk ritkán éri el az 1 métert.

Az ember után a második leginkább tájátalakító faj (Busher \& Dzieciolowski 1999). Építő tevékenységükkel fizikailag megváltoztatják környezetüket és ezzel közvetve befolyásolják a források elérhetőségét más fajok számára. Jelenlétük növeli egy területen az élővilág sokféleségét, segítenek a revitalizációban (Hood 2012). A természetvédelem fontos ,önkéntesei”: védelmüknek kiemelt jelentőséget kellene élveznie (Balodis et al. 1999). A hódok aktivitását nem lehet emberi beavatkozással pótolni. A vizek mentén emberi zavarástól mentes pufferzónákra lenne szükség, hogy a hódok által nyújtott ökoszisztéma szolgáltatások érvényesülhessenek (Messlinger 2012). Erre magyarországi példa is van: Tiszalúc mellett egy füzláp található. Évekig kiszáradva várta sorsát, a vízügyi és természetvédelmi szakemberek különféle beton mütárgyakkal tervezték a vízutánpótlást megoldani. A területen 2013-ban megtelepedett egy hódcsalád, és természetes anyagokból: fából és iszapból készített gátak segítségével felduzzasztották a vizet így a kiszáradt láp újra víz alá került (Czabán \& Arlett 2016).

A hód növényevő. Nyáron a vízpartokon gyakorlatilag korlátlan menynyiségben áll rendelkezésre lágyszárú táplálék, amit ezek az állatok szívesen fogyasztanak. Ebben az időszakban jelenlétük szinte észrevehetetlen a dús növényzet miatt. Összel, mikor a lágyszárú növényzet pusztulásnak indul, áttérnek a fás szárú táplálékra. Jellemzően október második felében jelennek meg az első rágások. A fadöntések csak akkor okoznak gondot és/vagy kárt, ha gazdasági erdőben, vagy belterületen, parkosított környezetben történnek.

Az ember előtti időkben 6-40 millió példány élhetett a kontinensen (MüllerSchwarze 2011), de jóval kiterjedtebbek voltak a vizes élőhelyek, valamint a hódokat is elejteni képes nagyragadozók sokkal nagyobb faj- és egyedszámmal bírtak. Az ember jelentősen átalakította az európai tájat: a nagyragadozókat jelentősen visszaszorította, ezen fajok egy része el is tünt (Gasparik \& Medzihradszky 2016), a vizes élőhelyek több mint $90 \%$-át lecsapolták. A hódok jelentős gazdasági értéket képviseltek egészen a 19. század végéig és majdnem sikerült őket kiirtani, mindössze kb. 1200 példány maradt belőlük a XX. század elejére (Nolet \& Rosell 1998). A divat változása mentette meg őket a kihalástól, amikor a luxuspiacról a hódprémet kiszorította a selyem (Allred 1986). Az 1920-as évektől kezdve európai szintủ védelmi intézkedések születtek és egészen a 2000-es évek elejéig tartott a visszatelepítési folyamat, ami igen sikeresnek bizonyult: 1996-ban közel 430.000 egyed élt (Nolet \& Rosell 1998), 2006-ban már 639.000-re nőtt 
a számuk (http://www.iucnredlist.org), 2011-ben pedig egyedszámuk elérte az 1 milliót (Müller-Schwarze 2011). A visszatelepítések mára már mindenhol befejeződtek és a védelmi intézkedéseket egyre inkább felváltják a konfliktuskezelési és állományszabályozási feladatok (Müller-Schwarze 2011). A hódok szinte egész Európában visszatértek, de az élőhelyeik végérvényesen megváltoztak. A szabályozott medrekben az állatok tevékenységükkel árvízvédelmi/természetvédelmi/ gazdasági gondokat okozhatnak, kevés az olyan terület, ahol ez a faj szabadon alakíthatja környezetét.

A Kárpát-medencéből az 1860-as években tünt el a faj (Lovassy 1927). Hosszú szünet után az 1990-es évek elején jelent meg újra, a Szigetközben, ausztriai telepítések nyomán. A WWF Magyarország 1996-2008 között 234 példányt engedett szabadon (Bajomi 2011). 2007-ben a hazai állományt 500 fósre (Márkus Ferenc, szem. közl.), 2011-ben 718-905 egyed közé becsülték (Bajomi 2011), 2015-ben már 2500-3000 (Czabán 2015), 2016-ban pedig legalább 4000 egyed élt hazánkban (Čanády et al. 2016, Czabán 2017).

A természetvédelmi hatóság felé az első hivatalos megkeresések 2011-ben érkeztek. Az ÉDUVIZIG 2012-ben nyújtott be először gátbontási kérelmet. Az első áttelepítési engedélyt 2014-ben adták ki Komáromban, azóta további áttelepítések történtek Nagyrédén (2016) és Jászberényben (2017-2018). 2016-ban és 2017-ben további megkeresések történtek áttelepítésekre a megyei hatóságok felé Tatáról, Szombathelyről, Vácrátótról is. 2016-ban az ÉDUVIZIG kért és kapott engedélyt 250 példány elejtésére, ebből 12 valósult meg. 2017-ben az ÉDUVIZIG szeretné a gyérítést tovább folytatni.

Mivel a hód védett, ezért a befogási kérelmek elbírálása a megyei hatóságok jogkörébe tartozik. Jól látható, hogy a különböző megyékben kiadott áttelepítési engedélyek nagymértékben különböznek annak függvényében, hogy az adott hivatalban hogyan gondolkodnak a hódokkal kapcsolatban. Nincsen egy egységes országos elképzelés arról, hogy hogyan lehet kezelni a szaporodó hódállomány következtében egyre gyakrabban jelentkező konfliktusokat. A Nemzeti Park Igazgatóságok egyre inkább vonakodnak befogadni az áttelepítendő családokat, mivel az ő müködési területükön is egyre gyakrabban szembesülnek a problémás családok kérdésével. Sajnos a hazai állományfelmérések nem egységesen fedik le az ország területét. Egyes területeken nagyon jó adatsorok állnak rendelkezésre, ilyen a Fertö-Hanság Nemzeti Park területe (Czabán 2017). De nagy „fehér foltok" is vannak, így nincs pontos kép a hazai állomány alakulásáról. 


\section{Javaslatok a hódos konfliktusok csökkentésére}

A „hódkonfliktusok” megoldására nem létezik egyetlen, mindenre jó megoldás, helyette többféle módszer kombinációja javasolt.

A Csehországban kidolgozott hármas zónarendszer módszere hazánkban is alkalmazható lenne. A csehek felosztották az ország területét: az „A” Zóna területén a hódok zavartalanul élhetnek és szaporodhatnak. Itt a természetes folyamatok érvényesülhetnek, az emberek nem szólnak bele az állomány változásába. A harmadik zónába („C” Zóna) olyan területek tartoznak, ahol a hódok jelenléte egyáltalán nem megengedett, az ott felbukkanó egyedek haladéktalanul eltávolíthatóak. A „B” Zóna területein a hód védelme alárendelt. Ebben a zónában a cél a hódok negatív hatásainak csökkentése, amik akadályoznák a fejlődést és az emberi területhasználatot. Törekedni kell a kompromisszumokra, ezért inkább a riasztási módszerek dominálnak, csak azokat az egyedeket/családokat távolítják el, amelyeket feltétlenül muszáj. Csehország területének 85,5\%-a ebbe a kategóriába tartozik (Korbelová et al. 2016).

Mivel a hódok leginkább a part közelében, a víztől számított 10-15 méteres sávban aktívak, a legjobb védekezés, ha ezen a területen meghagyják a természetes vízparti fás szárú növényzetet, amit leggyakrabban a füz- és nyárfajok alkotnak. Ezek könnyen felújulnak, bokrosodnak, ezáltal védő sávot képeznek a vízpart és a gazdasági területek között. Ennek nagy előnye, hogy a vadfajok számára átjárhatóak, a kerítéssel szemben. A bokrosodó növényzet számos egyéb állatfajnak jelent fészkelő- és búvóhelyet. Természetvédelmi szempontból ez a legjobb megoldás. A vízpartok mentén a vízügyi szakemberek rendszeresen alakítanak ki olyan utat, ahol medertisztítási és egyéb munkák során tudják ellenőrizni a partokat. Ilyenkor az úttól számított 10-15 méteres sávban az út másik oldalán található erdők irányába javasolt a természetes fás növényzet meghagyása. Habár ez az eljárás jelentősen csökkentené a gazdasági erdőkben ténylegesen jelentkező, a hódok által okozott károkat, a vízparton gazdálkodó szervezetek és magánszemélyek idegenkednek ettől, mert ezzel jelentős területek esnének ki a termelésből. De a jelenlegi helyzet sem tartható, mivel a gazdálkodót az erdészeti hatóság bünteti, ha hiányzik a fa az erdejéből, de ha pótolja a hódok által kidöntött példányokat, az állatok rövid idő alatt újra kidöntik azokat. Így a gazdálkodó kénytelen kerítéseket telepíteni, ha megnyugtatóan szeretné védeni az erdejét. Ha pedig erre a magángazdálkodóknak nincs pénzük, kénytelenek türni a kárt, és félő, hogy előbb-utóbb orvvadászati módszerekkel fogják rendezni a problémát (Lanszki 2009).

A hódok gátépítő tevékenysége miatt a megemelkedett vízszint eláraszthatja a környező területeket, ezáltal a terület müvelése ellehetetlenülhet. Lehetöséget kell 
teremteni arra, hogy a gazdák az érintett területeken a megváltozott körülményeknek megfelelő gazdálkodásra térhessenek át és ehhez egyszeri támogatást igényelhessenek. Ez a módszer a konfliktusok csökkentése mellett kedvező hatással lehet a vízfolyások természetességére, illetve hozzájárulhat új, természetes élőhelyek kialakulásához, ezen keresztül számos közösségi jelentőségủ faj állományának megőrzéséhez.

Kerítéssel hatékonyan távol lehet tartani a hódokat. Ennek kisebb erdőfoltok esetében van értelme, de sem természetvédelmi, sem vadvédelmi okokból nem előnyös, mivel kizárja a többi vadat is élőhelyük egy részéről, másrészt elzárja azokat a vízparttól. A kerítések telepítése költséges, másrészt folyamatos karbantartást igényelnek. A kerítéseknek célszerü a parttól legalább 4-5 méteres távolságot hagyni, mert a beszakadó üregek könnyen válhatnak a kerítés alatti átjáróvá.

A sekély vizü csatornákon, ahol a vízmélység kevesebb, mint 1 méter, a hódok rendszeresen építenek gátakat. A víz visszaduzzasztása helyenként gondokat okozhat a csatornarendszerekben és a környezö területeken, ezért a vízügyi szakemberek ezeket a gátakat elbontják, többnyire gépi erővel. A hódok a gátjaikat hamar, akár néhány napon belül újraépítik: a Hanságban több helyen a hódgátakat évente 50-60 alkalommal bontják, amiket az állatok jellemzően 2-4 napon belül újjáépítenek.

Az ÉDUVIZIG 2016-ban gyüjtött adatai szerint a müködési területükön 31 helyszínen bontották el ezeket a gátakat, nagyobb részüket több alkalommal is. A gátbontás alternatívája lehet a gátak becsövezése, túlfolyó beépítése. Ezek magyarországi alkalmazása természetesen lehetséges lenne, de eddig ez még sehol nem történt meg, szükséges lenne a módszer hazai körülmények közötti tesztelése.

A hódok nem telepednek meg egy területen, ha (1) a számukra szükséges téli fás szárú táplálékot teljesen eltávolítják, és/vagy (2) az üregásásra alkalmas partot kikövezéssel vagy fémrács lefektetésével megszüntetik. Ahol ezek már más okból megvalósultak, ott nem is jelentek meg hódok. Ezek a módszerek igen drágák, és természetvédelmi szempontból sem kívánatos gyakori alkalmazásuk. Nem alkalmazhatóak olyan vízfolyás mellett, ahol árnyaló állomány fenntartása szükséges a vízben élő közösségek megőrzése érdekében.

Ahol szükséges, a hódok létszám apasztása vadgazdálkodási módszerekkel lehetséges. Ma már Magyarországon szinte mindenhol élnek, vagy várható megjelenésük, ezért természetvédelmi szempontból nem indokolt és nem kívánatos az egyedek átszállítása. A Györ-Moson-Sopron megyei Kormányhivatal Környezetvédelmi és Természetvédelmi Főosztályának korábbi megkeresésére egyik hazai nemzeti park sem akart befogadni példányokat, arra hivatkozva, hogy az ő területeiken is élnek már nagyobb egyedszámban. Territoriális fajok esetében, ha hirtelen sok új egyed jelenik meg egy olyan területen, ahol ott élő fajtársak már 
elfoglaltak saját területeket, a rezidens családok az újakkal harcokat folytatnak majd az élőhelyekért. Ugyanez a jelenség már telítődött élőhelyeken is megfigyelhetö, például Németországban, az Elba mentén (Gerhard Schwab hódmenedzser szem. közl.). Ezért javasolt a felesleges egyedek kíméletes elpusztítása. Az egyedek kivételére a legjobb módszer a csapdázás, amely hatékony is, másrészt szelektív. Ha más faj kerül a csapdába, az egyed sérülés nélkül szabadon engedhető. Nyugat-Európában a természetvédelem egyik célja, hogy fenntartson alkalmas és kolonizálható, szabad élőhelyeket (Nolte et al. 2003). Nagyragadozók hiányában ehhez időnként apasztani kell a populáció egyedszámát. Erre nincsen egyértelmü, mindenhol alkalmazható iránymutatás sehol Európában. A hódállomány jelentős gyérítése várhatóan komoly társadalmi felháborodást eredményezhet. A konfliktust felvilágosító kampánnyal és tájékoztatással meg lehet előzni. Az ember által átalakított tájban az együttélés lehetséges, de fontos, hogy kidolgozzuk és alkalmazzuk azokat a módszereket, amelyek jelentősen csökkenthetik a konfliktusok kialakulásának lehetőségét.

\section{Irodalomjegyzék}

Allred, M. (1986): Beaver behavior: architect of fame and bane. - NatureGraph Publ., Happy Camp, CA, $110 \mathrm{p}$.

Bajomi, B. (2011): Az eurázsiai hód (Castor fiber) visszatelepitésének tapasztalatai Magyarországon. - DDNPI tanulmány. „Danubeparks” (SEE/A/064/2.3/X) pályázat. 54 p.

Balodis, M., Laanetu, N. \& Ulevicus, A.. (1999): Beaver management in the baltic states. - In: Busher, P. E. \& Dzieciolowski, R. M. (szerk.): Beaver protection, management, and utilization in Europe and North America. New York: Kluwer Academic/Plenum, pp. 25-30.

Busher P. E. \& Dzieciolowski, R. M. (eds) (1999): Beaver protection, management, and utilization in Europe and North America. - New York: Kluwer Academic/Plenum, 182 p.

Czabán, D. (2003): A Hanságba visszatelepitett hódok (Castor fiber) élöhely- és táplálékválasztási szokásai. - MSc diplomadolgozat, ELTE TTK, Budapest, 71 p.

Czabán, D. (2013): Éljünk együtt a hódokkal, de hogyan? - WWF Magyarország, Budapest, 41 p.

Czabán, D. (2015): Hódok a Szigetközben. - In: Korda, M. (szerk): Az erdögazdálkodás hatása az erdők biológiai sokféleségére. Duna-Ipoly Nemzeti Park Igazgatóság, Budapest, pp. 403-418.

Czabán, D. (2017): A hód állományának vizsgálata az FHNP müködési területén (2017). -FertöHanság Nemzeti Park Igazgatóság, Sarród, 46 p.

Czabán, D. \& Arlett, P. (2016): Hódállomány felmérés a Kesznyéteni Sajó-öböl (HUBN20069) Natura 2000 site területén. - WWF Magyarország, Budapest, 6 p.

Gasparik, M. \& Medzihradszky, Zs. (2016): A mi jégkorszakunk-Pleisztocén élővilág a Kárpátmedencében. - Magyar Természettudományi Múzeum, Budapest, 218 p.

Hood, G. A. (2012): Biodiversity and ecosystem restoration: Beavers bring back balance to an unsteady world. - In: Book of Abstracts. 6th International beaver symposium 17-20, 09, 2012 Ivanic-Grad, Croatia. pp. 43.

Jones, C. G., Lawton, J. H. \& Shackak, M. (1994): Organisms as ecosystem engineers. - Oikos 69: 373-386. doi: https:// doi.org/10.2307/3545850 
Korbelová, J., Vores, A. \& Uhlíková, J. (2016): Management Plan for the Eurasian Beaver in the Czech Republic. - In: Vorel A. \& Korbelová J. (szerk.): Handbook for Coexisting with Beavers. Czech University of Life Sciences Prague. Prague, pp. 20-24.

Lanszki, J. (2009): Vadon élö vidrák Magyarországon. - Natura Somogyiensis 14, 238 p.

Lovassy, S. Dr. (1927): Magyarország gerinces állatai és gazdasági vonatkozásaik. - Királyi Magyar Természettudományi Társulat, 895 p.

Messlinger, U. (2012): Beavers boosting biodiversity-Monitoring some animal world in North-Bavarian beaver sites. - In: Book of Abstracts. 6th International beaver symposium 17-20, 09, 2012 Ivanic-Grad, Croatia, pp. 51.

Müller-Schwarze, D. (2011): The beaver. Its Life and Impact. Second edition. - Cornell University Press, $216 \mathrm{p}$.

Nolet, B. A. \& Rosell, F. (1998): Comeback of the beaver, Castor fiber: an overview of old and new conservation problems. - Biol. Conserv. 83: 165-173. doi: https://doi.org/10.1016/S00063207(97)00066-9

Nolte, D. L., Lutman, M. W., Bergman, D. L., Arjo, W. M. \& Perry, K. R. (2003): Feasibility of non-lethal approaches to protect riparian plants from foraging beavers in North America. - In: G. R. Singleton, L. A. Hinds, C. J. Krebs \& D. M. Spratt (szerk.): Rats, mice and people: rodent biology and management. Canberra: Australian Centre for International Agricultural Research, pp. 75-79.

Parker, H. \& Rosell, F. (2012): Beaver Management in Norway - A Review of Recent Literature and Current Problems. - Telemark University College, Porsgrunn, 61 p. 


\title{
Beavers came back - Is it blessing or curse?
}

\author{
Dávid Czabán ${ }^{1}$ and Tamás Gruber ${ }^{2}$ \\ ${ }^{1}$ Kaposvár University, Department of Game Biology and Ethology \\ ${ }^{2}$ WWF Hungary
}

The eurasian beaver (Castor fiber) is a native species which almost extincted in the beginning of the 20th century but already recolonised its former distribution. This species turned up in Hungary in the beginning of the 1990s in Szigetköz area after the austrian reintroductions. WWF Hungary released 234 specimens between 1996-2008. The Hungarian population was estimated 500 ind. in 2007, 718-905 ind. in 2011, 2500-3000 ind. in 2015 and min. 4000 ind. in 2016 and 2017. They live everywhere in Hungary but the monitoring is not regular. More and more beavers turn up in human environment but serious conflicts are known only from Fertö-Hanság National Park. It is the second greatest landscape alterating species after humans, their impact can be positive and negative too. The heaviest conflicts are (1) wood laying can cause serious damages; (2) digging can decrease the strength of the dykes; and (3) the beaver dams can cause large areas flooded. There are effective solutions that should be tested in Hungarian environment and a Hungarian beaver managing plan should be developed. A zone system is offered which sould be similar to the Czechish system where Zone "A" is a protected area for beavers. In Zone „C" beavers can be removed immediately. In Zone „B" the beaver protection is subordinated to land use and other interests of people in the landscape where the purpose is to limiting the negative impacts of beavers.

Keywords: Eurasian beaver, beaver management, game impact, population control 